\title{
Effects of Residential Wood-Burning Emissions during Winter Months in a Northern San Diego County Location
}

Sarah $\mathbf{S}^{1}$, Jorge ${ }^{1}$, Shekar $\mathbf{V}^{1^{\star}}$ and William ${ }^{2}$

${ }^{1}$ National University, 3678 Aero Court, San Diego, CA 92123 USA

${ }^{2}$ San Diego Air Pollution Control District, 10124 Old Grove Road, San Diego, CA 92131, USA

\begin{abstract}
Ambient particulate matter $\left(\mathrm{PM}_{10}\right.$ and $\left.\mathrm{PM}_{25}\right)$ and carbon monoxide $(\mathrm{CO})$ due to domestic wood burning during the winter and summer months in the city of Escondido were investigated. The data collected from January 2000 to December 2010 from San Diego Air Pollution Control District's (SDAPCD's) collection station in Escondido were analyzed by both non-paired student's t-tests and Mann-Whitney $U$ tests (significance of 0.05 for both tests). For all three pollutants, the significant differences in levels between the winter and summer months, the significant differences in levels during the days that were celebrated as holidays and normal days, and the significant differences in levels between weekends and weekdays were noted. Additionally, the significant differences in levels between night and daytime, early evening hours and night and during burning and smoldering fires were determined for hourly $\mathrm{PM}_{2.5}$ and $\mathrm{CO}$ data. For all emission types, traffic patterns did not match the levels of emissions on weekdays, weekends, evenings, or daytimes. Elemental and organic carbon species taken from $\mathrm{PM}_{2.5}$ data correlated with the original $\mathrm{PM}_{2.5}$ filter data. Results of our analysis suggest that wood burning is a source of $\mathrm{PM}_{10}^{2.5}, \mathrm{PM}_{2.5}$, and CO in the area.
\end{abstract}

Keywords: Residential wood burning; Biomass burning; $\mathrm{PM}_{10}$; $\mathrm{PM}_{2.5}$; CO; Smoldering fires

\section{Introduction}

Residential wood burning is common throughout San Diego County in the wintertime. Some areas get significantly colder than others, and a higher quantity of wood is burned during these colder times. Residential wood burning results in higher ambient concentrations of emissions including particulate matter $\left(\mathrm{PM}_{10}\right.$ and $\left.\mathrm{PM}_{25}\right)$, carbon dioxide $\left(\mathrm{CO}_{2}\right)$, carbon monoxide $(\mathrm{CO})$, nitrogen oxides $\left(\mathrm{NO}_{\mathrm{x}}\right)$, Polycyclic Aromatic Hydrocarbons (PAH's), and aldehydes $[1,2]$. Maenhaut also saw seasonal variations in $\mathrm{PM}_{10}$ levels in Belgium, and separated elemental and organic carbon to specifically contribute these varying emission levels to wood burning in the region [3].

Some domestic wood burning emissions are of public concern because they are detrimental to the environment and human health. It was found that in San Jose, California, $42 \%$ of the $\mathrm{PM}_{10}$ generated during winter months originated from wood smoke [4]. In Portugal, $18 \%$ of $\mathrm{PM}_{10}$ emissions were due to residential wood burning, and eliminating wood burning in a particular area reduced emissions by $46 \%$ [5]. This suggests that the overall content of $\mathrm{PM}_{10}$ in the air could have a significant effect on the population's health during winter months. In addition, avocado wood, one of the dirtiest-burning woods available in the San Diego area produces more particulate matter than other wood types [6]

The physical conditions at the time the wood is burned can also impact the chemical composition of the released emissions, and can affect human health [7]. Also, the levels of $\mathrm{PM}_{10}$ and $\mathrm{PM}_{2.5}$, as well as $\mathrm{CO}$ present in wood burning emissions will theoretically be different from each other depending on whether they are a product of actively burning fires or smoldering fires. Differences in temperature of the fire positively correlate with the efficiency of the combustion process. Fires begin burning with a high temperature and are barely efficient in terms of turning fuel into products. In other words, high temperature fires release more gases, such as $\mathrm{CO}$ and hydrocarbons, than particulates, which could be of concern if they are released in a poorly ventilated area. Then, as the fire continues with less fuel and becomes more of a smoldering fire, the temperature lowers, and the fire releases more particulates and water than gases [2].

\section{The area of concern}

Escondido, an incorporated area in the northern part of San Diego County, is an ideal location to study air quality because of its geographic and demographic characteristics. Tian et al. [8] suggests that demographics such as age and number of people in each household, income, and urban or rural infrastructure can have an effect on the measurements of particulate matter in a particular area. Escondido has a population of 143,389 (2008 census), and the largest percentage of the population is between the ages of 15 and 64 . The average number of people in each household was 3.08 in 2008. In 2010, 36\% of households earned less than $\$ 30,000$ per year, but $10 \%$ of households earned more than $\$ 100,000$ per year [9]. This suggests that people in the same geographic area do have access to different sources of heat in the home.

Escondido covers a range in elevation from 400 feet to 2100 feet [9]. Located mostly in a valley at the base of the coastal range mountains, and relatively near the coast, the city has its lowest temperatures in the winter and some of the highest in the summer. Data from NOAA Climatic Data Center show that the monthly mean temperatures in Escondido in November, December, and January during the study period are $31^{\circ} \mathrm{F}, 28^{\circ} \mathrm{F}$, and $27^{\circ} \mathrm{F}$, respectively [10]. These temperatures certainly require heating of the homes in the city and surrounding areas, resulting in wood burning during these months.

The low winter temperatures and surrounding terrain make the location prone to trapping air pollutants, especially during the coldest

*Corresponding author: Shekar Viswanathan, National University, 3678 Aero Court, San Diego, CA 92123 USA, Tel: 858-309-3416; E-mail: sviswana@nu.edu

Received November 10, 2014; Accepted January 20, 2015; Published January 25,2015

Citation: Sarah E, Jorge C, Shekar V, William CB (2015) Effects of Residential Wood-Burning Emissions during Winter Months in a Northern San Diego County Location. J Environ Anal Toxicol 5: 266. doi:10.4172/2161-0525.1000266

Copyright: ( 2015 Sarah E, et al. This is an open-access article distributed under the terms of the Creative Commons Attribution License, which permits unrestricted use, distribution, and reproduction in any medium, provided the original author and source are credited. 
times of the year. A nocturnal inversion causes the wood burning emissions to be trapped within the shallow surface layer above the valley during the night and early morning hours. Because the region is mountainous, the possibility for the polluted air to disperse becomes difficult. As a result, the pollutants linger over the valley in colder, wintertime temperatures, thus increasing the city's exposure to their effects [6].

\section{Measuring San Diego's ambient air pollutant concentration}

Ambient air quality is measured at nine different locations throughout the county by the San Diego Air Pollution Control District (SDAPCD). In 2009, SDAPCD reported that Escondido ranked among the cities with the highest annual levels of $\mathrm{PM}_{2.5}$ from 1999 to 2009 [11]. The objective of this project is to develop a methodology to identify residential wood burning as a major contributor to the higher ambient concentrations of $\mathrm{PM}_{10}, \mathrm{PM}_{2.5}$, and $\mathrm{CO}$ in Escondido during winter months (November, December, January) and on holidays. In addition, this study's focus is on the types of fire burned in domestic fireplaces, and the weather patterns in the area of study. The types of wood burned, the physical condition of people in the affected areas, and any weather phenomena can ultimately change the overall air quality in the wintertime, and can amplify the effects of poor air quality on the nearby population.

\section{Literature Review}

Wood burning used for heating and cooking is the most common type of biomass burning around the world. When wood burns, it generates gases and particles including $\mathrm{PM}_{10}$ and $\mathrm{PM}_{25}$. These emissions also contain high arsenic concentrations, $\mathrm{CO}$, polycyclic aromatic hydrocarbons, benzopyrene, as well as a mixture of condensable organic products that conglomerate and solidify [12-14]. During the coldest times of the year, wood consumption increases worldwide, including most parts of the U.S. [15]. The effect of wood burning emissions on human health has become a key concern in recent years. A long-time exposure to wood smoke has been associated with the dwarfing of children, wheezing in children, and cardiovascular and respiratory illnesses $[14,16]$.

The emissions from wood burning are influenced by the size and the moisture level inside the wood. Thicker and moister logs burn less efficiently. As a result, burning such logs can create higher concentrations of particulate matter in the air than other gases [17]. A fireplace furnace is not a very efficient heat source because most of the heat exits up the chimney stack with the smoke [14]. When wood is burned, the gaseous products are released when pyrolysis temperatures are reached [15]. Organic materials are transformed into gaseous components and solid residue which are composed of fixed carbon and ash [18]. The denser, cold air near the surface from the evening temperature inversion, combined with the average residential chimney stack's closeness to the ground is cause for the wood burning emissions to remain in the lower atmosphere. Inversions trap cold air under a layer of warmer air. The cold and dense air then limits the vertical dispersion of the hot chimney fumes that contain the emissions, keeping them at lower altitudes. These particles linger close to the ground and increase the ambient concentration of emissions in the affected area.

The most common types of wood burned around San Diego County are oak, eucalyptus, avocado, and pine. Kleeman, et al. [6] studied the chemical composition of the particles emitted during oak, pine, and eucalyptus wood burning. The samples measured were $17.2 \mathrm{~kg}$ of pine (burned for $189 \mathrm{~min}$ ), $15.4 \mathrm{~kg}$ of oak (burned for $165 \mathrm{~min}$ ), and $18.9 \mathrm{~kg}$ of eucalyptus (burned for $218 \mathrm{~min}$ ). The particles emitted by the wood samples burning were primarily composed of organic compounds with a mass distribution that peaked between 0.1-0.2 $\mu \mathrm{m}$ in diameter, which meant they were all categorized as $\mathrm{PM}_{2.5}[6]$.

The weather also affects the air quality in southern California. California weather patterns are influenced by the Pacific High (PH) and the Aleutian Low (AL) pressure systems. The interaction of these two circulation systems determines the air exchange along the west coast of the U.S. The air exchange is also influenced by the peninsular mountain chains that run along the California coast, impeding the coastal air's movement. These pressure systems and the inland mountains allow for a marine layer over the coast. The local marine layer is restricted to a depth of 3,000 feet or less. A subsidence inversion occurs, and traps the marine air which also captures pollutants and smog.

Additionally, wind from a specific weather event could either disperse the marine layer or move air that is higher in emissions to other locations in the county, or move air inland faster than would have happened without the wind event. Southern California is not prone to severe wind weather events such as tornadoes. San Diego county, and Escondido in particular, saw zero wind events of 74 miles per hour or higher (the definition of a Category 1 weather event) during the study period [19].

\section{Methodology}

To estimate the impact of the pollutants released by wood burning in the area of Escondido, a baseline ambient concentration level was established [20]. The data recorded at the SDAPCD's Escondido collection station were sorted and analyzed in terms of the monthly averages for the 11 years studied (2000 to 2010). Daily values were available for $\mathrm{PM}_{10}$ and $\mathrm{PM}_{2.5}$, and hourly data were available for $\mathrm{CO}$ from 2000 to 2010, and for $\mathrm{PM}_{25}$ from 2008 to 2010 [20]. Before each test was completed, the entire data set was sorted by time and parameter, and the non-applicable data was eliminated. Statistical tests compared winter months and summer months, holiday times to the rest of the winter, weekends and weekdays, evenings and daytime, early evening hours and night, and burning to smoldering fires for each of the parameters, namely $\mathrm{PM}_{10}, \mathrm{PM}_{25}$, and $\mathrm{CO}$.

Excel was a useful tool in sorting the large data sets and comparing data efficiently. Both Student's t-tests and Mann-Whitney U-Tests (MWU) were used in Excel to compare the data sets and determine if they were statistically different from each other. The t-test is used for smaller sample sizes (ranging from $n=2$ to $n=30$ ) and computes, then compares the means using a p-value (value that indicates level of significance) to determine if the samples are significantly different from one another. The MWU test ranks the data in ascending order and uses rank sums to generate a $z$-value (value that indicates significance based on percent confidence and the critical value) that is then used on a standard distribution curve to determine significance. This test is more reliable than a t-test for very large sample sizes, such as those in the thousands, or where sample sizes in the two groups are very different from each other. Each of these tests were appropriate for this study because the study compared only two groups and each comparison used only one independent variable. Each test was done with a significance level of 0.05 ( $95 \%$ confidence).

For the summer versus winter tests, all data were separated by parameter $\left(\mathrm{PM}_{10}, \mathrm{PM}_{25}\right.$, or $\left.\mathrm{CO}\right)$, ordered by date, and then separated by month. Each month of data were categorized as summer or winter (summer defined as February-October and winter defined as 
November-January based on the time that fireplaces are active in this area of California). Then each larger data set was compared using both types of statistical tests. All dates without data collected were eliminated before testing to avoid false results.

To further test for conditions within winter months, the winter data were again separated by type, ordered by date, eliminated if no data were collected, and then categorized for each test to create a complete data set for each parameter. The tests included the following:

- Weekend (Saturday and Sunday) versus Weekday (Monday through Friday): This test was done to separate possible high values of these pollutants from traffic patterns and actually attribute possible pollutant contributions to fireplace emissions instead of another source.

- Christmas Day (December $25^{\text {th }}$ ) versus Christmas Week (December $23^{\text {rd }}$ to December $27^{\text {th }}$ ): Many people take vacation to be home with family during this time and school is often out for the holiday week.

- New Year's Day (January $1^{\text {st }}$ ) versus New Year's Week (December $28^{\text {th }}$ to January $3^{\text {rd }}$ ): These two holiday comparisons were defined as two days before and two days after because the data were collected over multiple years where the holidays and school breaks fell on different weekdays.

- $\quad$ Two holiday weeks (December $22^{\text {nd }}$ to January $4^{\text {th }}$ ) versus winter months (November through January except for the two weeks aforementioned): This test was done to determine if higher emission concentrations in the area were attributed to domestic wood burning during the holidays compared to the rest of winter.

CO (2000 to 2010) and some $\mathrm{PM}_{25}$ data (2008 to 2010) were collected hourly instead of once per day. This data were subjected to the same tests in the same way as the data above, as well as some additional, more specific tests. To complete these tests, the data from winter months were sorted by date, then by time and separated based on the parameters of each test. We tested for the following:

- Night (6:00 pm-12:00 am, active fire times only) versus Daytime (6:00 am-5:00 pm): The time frame of 6 am to $5 \mathrm{pm}$ was determined to be 'daytime' because this is a window that incorporates the morning and evening traffic rush, as well as most of the commercial traffic during the day. The 'night' time frame was defined as $6 \mathrm{pm}$ to 12 am because this window incorporates the assumed time that people use their fireplaces before falling asleep and letting them burn out or continue smoldering.

- Early evening hours (6:00 pm-9:00 pm) versus the rest of the night (10:00 pm-6:00 am): This test was to separate traffic as a possible source of higher ambient concentrations of emissions in early evening hours from other possible sources at night.

- $\quad$ Burning fire times (6:00 pm-12:00 am) versus smoldering fire times (1:00 am-7:00 am): This test was to determine if ambient concentrations of emissions were higher when people first got home in the evenings and maintained a burning fire, or if the emission concentrations were higher when the fires were not maintained and were left as smoldering coals. The reason for the possible difference can be attributed to the fact that burning and smoldering fires are different in their burning efficiency and could possibly be creating chemically unique emissions.

All tests listed above were done by both Student's t-test and the
MWU test (Table 1). Of course, without any available data revealing the actual fireplace usage of the residents in and around Escondido, the times of the parameters were assumed and chosen based on the temperatures in the area and the normal traffic patterns.

To assist in attributing high concentrations of all these pollutants to wood burning, the data were analyzed over the New Year's holiday to determine if there was a peak in ambient concentrations specifically on this night of the year over all years studied. For daily data points $\left(\mathrm{PM}_{10}\right.$ and $\left.\mathrm{PM}_{25}\right)$, averages of all data collected December $30^{\text {th }}$ through January $2^{\text {nd }}$ were calculated and graphed. For hourly data points (CO and $\mathrm{PM}_{2.5}$ ), averages of all data collected were graphed from 0:00 on December $30^{\text {th }}$ to 23:00 on January $1^{\text {st }}$ to show hourly changes. Assuming that there would be a significant increase in emission concentrations over the New Year's holiday, data for July $4^{\text {th }}$ were also graphed for each parameter in order to rule out fireworks that happen on both July $4^{\text {th }}$ and New Year's as the source of higher ambient concentrations.

To eliminate traffic as a major source of these particulate emissions, the daily and hourly traffic for January 2012 in the area were analyzed with traffic volumes along with ambient pollutant concentrations. In addition, all emissions data available from 2000 to 2010 were averaged by each day or hour, depending on whether the sample was collected daily or hourly, and then graphed against the matching traffic data sets.

To further assess whether $\mathrm{PM}_{2.5}$ ambient concentrations were due to fireplace emissions, the speciated carbon data from 2001 to 2007 were separated into elemental and organic carbon totals, and then plotted against the other collected filter data over time to look for correlations in changing emissions levels.

\section{Results and Discussion}

The findings are presented in time series plots, separated by air pollutant type over the entire period studied. Table 2 shows a summary of all results, including significance and corresponding $\mathrm{p}$-values and z-values.

$\mathbf{P M}_{10}$

As expected, emissions in winter months are significantly higher than summer months $(\mathrm{p}=0.0305, \mathrm{z}$-value outside $\mathrm{z}$-critical) (Table 2 ). The two holiday weeks (December $22^{\text {nd }}$ to January $4^{\text {th }}$ ) showed significantly higher $\mathrm{PM}_{10}$ concentrations than the rest of the winter months ( $\mathrm{p}=0.0198, \mathrm{z}$ was outside $\mathrm{z}$-critical) (Table 2 ). The results indicated these weeks had the most elevated $\mathrm{PM}_{10}$ concentrations for the entire year. No test was conducted to determine if the traditional holiday days, Christmas and New Year's, were marked by significantly higher ambient $\mathrm{PM}_{10}$ concentrations than the rest of their corresponding weeks because of the lack of a sufficient number of daily samples on these holidays (samples were taken every six days).

As shown in Table 2, weekend $\mathrm{PM}_{10}$ concentrations are not significantly higher than weekday concentrations $(\mathrm{p}=0.6957, \mathrm{z}$ was not outside $\mathrm{z}$-critical). However, the average $\mathrm{PM}_{10}$ concentration of the weekend group was higher in value than the average concentration of the weekday group (Table 2). Figure 1 shows the average $\mathrm{PM}_{10}$ monthly levels over the 11 years of data that were collected. The bold line on the graph at $50 \mu \mathrm{g} / \mathrm{m}^{3}$ shows the California state standard and the trend line shows that the average concentrations have slightly decreased over the decade. The peak at October 2003 and again at October of 2007 can be attributed to the county-wide wildfires during these months [17] These values were not excluded from this analysis. 


\begin{tabular}{|c|c|c|c|c|c|c|c|}
\hline Comparison & $\begin{array}{c}\text { Summer } \\
\text { vs. } \\
\text { Winter Months }\end{array}$ & $\begin{array}{l}\text { Two Holiday Weeks } \\
\text { vs. } \\
\text { Winter Months }\end{array}$ & $\begin{array}{l}\text { Holiday Days } \\
\text { vs. } \\
\text { Holiday Week }\end{array}$ & $\begin{array}{l}\text { Weekend } \\
\text { vs. } \\
\text { Weekday }\end{array}$ & $\begin{array}{l}\text { Night } \\
\text { vs. } \\
\text { Daytime }\end{array}$ & $\begin{array}{c}\text { Early Evening Hours } \\
\text { vs. } \\
\text { Night }\end{array}$ & $\begin{array}{l}\text { Burning } \\
\text { vs. } \\
\text { Smoldering }\end{array}$ \\
\hline $\mathrm{PM}_{10}$ & $x$ & $x$ & Not Enough Data & $x$ & $24 \mathrm{hr}$ Sample & $24 \mathrm{hr}$ Sample & $\begin{array}{c}24 \mathrm{hr} \\
\text { Sample }\end{array}$ \\
\hline $\mathrm{PM}_{2.5 \text { Daily }}$ & $x$ & $x$ & $x$ & $x$ & $\begin{array}{c}24 \mathrm{hr} \\
\text { Sample }\end{array}$ & $\begin{array}{c}24 \mathrm{hr} \\
\text { Sample }\end{array}$ & $\begin{array}{c}24 \mathrm{hr} \\
\text { Sample }\end{array}$ \\
\hline $\mathbf{P M}_{2.5 \text { Hourly }}$ & $x$ & $x$ & $x$ & $x$ & $x$ & $x$ & $x$ \\
\hline CO & $x$ & $x$ & $x$ & $x$ & $x$ & $x$ & $x$ \\
\hline
\end{tabular}

Table 1: Summary of Tests Conducted for Each Pollutant Collected from January 2000 to December 2010. An "X" in the box indicates the presence of enough data to test.

$\mathbf{P M}_{2.5}$

$\mathrm{PM}_{2.5}$ data were tested to compare summer versus winter months, the two holiday weeks together versus winter months, the holiday days versus their corresponding week, and weekend versus weekday levels (Table 2). The results showed that the $\mathrm{PM}_{25}$ concentrations for winter months were significantly higher than the summer months ( $\mathrm{p}=0.001, \mathrm{z}$ outside $\mathrm{z}$-critical), which was expected. The two holiday weeks (December $22^{\text {nd }}$ to January $4^{\text {th }}$ ) showed significantly higher concentrations of $\mathrm{PM}_{25}$ than the rest of the winter months $(\mathrm{p}=0.0002, \mathrm{z}$ outside $\mathrm{z}$-critical) (Table 2). The $\mathrm{PM}_{2.5}$ levels for the traditional holiday days, Christmas and New Year's, were higher in average value than the rest of their corresponding weeks (December $23^{\text {rd }}$ to $27^{\text {th }}$ and December $28^{\text {th }}$-January $3^{\text {rd }}$, respectively). $\mathrm{PM}_{2.5}$ concentrations for Christmas were not significantly higher than the rest of the week $(p=0.080, z$ outside $\mathrm{z}$-critical contrary to t-test; $\mathrm{t}$-test values are more reliable for this sample size, so the result is considered significant), but they were significantly higher for New Year's Day ( $\mathrm{p}=0.049$, $\mathrm{z}$ outside $\mathrm{z}$-critical) (Table 2). $\mathrm{PM}_{2.5}$ concentrations for weekends were significantly higher than for weekdays ( $\mathrm{p}=0.032, \mathrm{z}$ outside $\mathrm{z}$-critical).

Figure 2 shows the average monthly concentrations of $\mathrm{PM}_{25}$ over 11 years. The bold line on the graph at $35 \mu \mathrm{g} / \mathrm{m}^{3}$ shows the federal 24 hour standard level and the trend line shows that the average $\mathrm{PM}_{2.5}$ concentrations, like $\mathrm{PM}_{10}$, have decreased over the decade. As shown in Table 2, hourly data points for $\mathrm{PM}_{25}$ from 2008 to 2010 were also tested in the same fashion as daily $\mathrm{PM}_{10}$ and $\mathrm{PM}_{2.5}$ values, as well as night versus day, early evening versus the rest of the night, and burning versus smoldering tests. Winter $\mathrm{PM}_{25}$ concentrations were significantly higher than summer ( $\mathrm{p}=0, \mathrm{z}$ outside $\mathrm{z}$-critical). $\mathrm{PM}_{2.5}$ concentrations over the two holiday weeks (December $22^{\text {nd }}$ to January $4^{\text {th }}$ ) were significantly higher than winter months $(\mathrm{p}=0, \mathrm{z}$ was outside $\mathrm{z}$-critical) (Table 2). Christmas Day ( $\mathrm{p}=0.001, \mathrm{z}$ was outside $\mathrm{z}$-critical) and New Year's Day ( $\mathrm{p}=0, \mathrm{z}$ was outside $\mathrm{z}$-critical) $\mathrm{PM}_{2.5}$ concentrations were both significantly higher than their corresponding weeks.

Weekend $\mathrm{PM}_{2.5}$ concentrations were higher than on weekdays ( $\mathrm{p}=0.028, \mathrm{z}$ outside $\mathrm{z}$-critical). Nighttime $\mathrm{PM}_{25}$ concentrations were significantly higher than daytime $(\mathrm{p}=0, \mathrm{z}$ was outside $\mathrm{z}$-critical) (Table 2). The ambient $\mathrm{PM}_{2.5}$ concentrations during early evening hours were not significantly higher than those collected during the rest of the night ( $\mathrm{p}=0.195, \mathrm{z}$ was not outside $\mathrm{z}$-critical). Finally, data collected during burning times showed $\mathrm{PM}_{25}$ concentrations were significantly higher than those during smoldering times $(\mathrm{p}=0, \mathrm{z}$ was not outside $\mathrm{z}$-critical; contrary to t-test, $t$-test values are more reliable for this sample size, so the result is considered significant) (Table 2).

\section{Monoxide}

Carbon monoxide (CO) data used for this study were collected on an hourly basis, while most PM data provided were collected daily. CO was tested for summer versus winter months, the two holiday weeks together versus winter months, the holiday days versus the other days in their corresponding week, weekends versus weekdays, night versus daytime, early evening versus night, and burning versus smoldering, which is essentially the first half of the night versus the latter half of the night (Table 2). The results showed that $\mathrm{CO}$ concentrations in winter months were significantly higher than during the summer months ( $\mathrm{p}=0.001, \mathrm{z}$ was outside $\mathrm{z}$-critical). The two holiday weeks (December $22^{\text {nd }}$ to January $4^{\text {th }}$ ) showed significantly higher ambient concentrations of $\mathrm{CO}$ than the rest of the winter months ( $\mathrm{p}=0, \mathrm{z}$ was outside $\mathrm{z}$-critical) (Table 2). The traditional holiday days, Christmas and New Year's, showed a higher average concentrations of $\mathrm{CO}$ than the rest of their corresponding weeks, but were not significantly higher (Christmas Day $\mathrm{p}=0.086, \mathrm{z}$ was not outside $\mathrm{z}$-critical, New Year's Day $\mathrm{p}=0.061$, $\mathrm{z}$ was not outside $\mathrm{z}$-critical). This makes the combined two holiday weeks the highest in average concentrations of $\mathrm{CO}$ in the year.

As shown in Table 2, the weekend $\mathrm{CO}$ concentrations were significantly higher than weekdays ( $\mathrm{p}=0.0002$, $\mathrm{z}$ was outside $\mathrm{z}$-critical). Early evening hour concentrations were significantly higher than the rest of the night ( $\mathrm{p}=0, \mathrm{z}$ was outside $\mathrm{z}$-critical). Nights were marked by significantly higher concentrations of $\mathrm{CO}$ than daytimes $(\mathrm{p}=0$, $\mathrm{z}$ was outside $\mathrm{z}$-critical), and the same occurred for burning versus smoldering times ( $\mathrm{p}=0, \mathrm{z}$ outside $\mathrm{z}$-critical) (Table 2$)$.

Figure 3 shows average monthly ambient concentrations of CO over 11 years. The error bars on each monthly average are the minimums and maximums in the month. The high values in October 2003 can also be attributed to the county-wide wildfires [17]; however, these high concentrations were not seen during the October 2007 wildfires due to the location of the fires relative to the monitoring station. Statistical calculations did not exclude these values.

\section{Additional holiday analysis}

Figure 4 shows the average daily concentrations of $\mathrm{PM}_{2.5}$ and $\mathrm{PM}_{10}$ from December $30^{\text {th }}$ to January $2^{\text {nd }}$ plotted as daily values over all years collected. These data show the peak in values over the New Year's holiday where people burn fires not only for heat, but also, because they stay up until midnight, as is customary to the holiday. Actively burning fires emit more gases than smoldering fires, so if they are active for a longer period of time over the holiday, as opposed to smoldering for many hours, the concentrations of gaseous emissions in the coldest hours of the night are higher. Higher ambient concentrations of particulate matter may also be expected because the holiday is in the wintertime during a period when the temperature inversion traps emissions in the area.

Figure 5 shows the hourly averages of $\mathrm{PM}_{2.5}$ and $\mathrm{CO}$ concentrations over the 48 hour period of December $31^{\text {st }}$ to January $1^{\text {st }}$ for all years collected. $\mathrm{PM}_{2.5}$ hourly data were collected and averaged from 2008 to 2010. CO hourly data were collected and averaged from 2000 to 2010.

Analysis of data collected during New Year's holiday for each 
Citation: Sarah E, Jorge C, Shekar V, William CB (2015) Effects of Residential Wood-Burning Emissions during Winter Months in a Northern San Diego County Location. J Environ Anal Toxicol 5: 266. doi:10.4172/2161-0525.1000266

Page 5 of 9

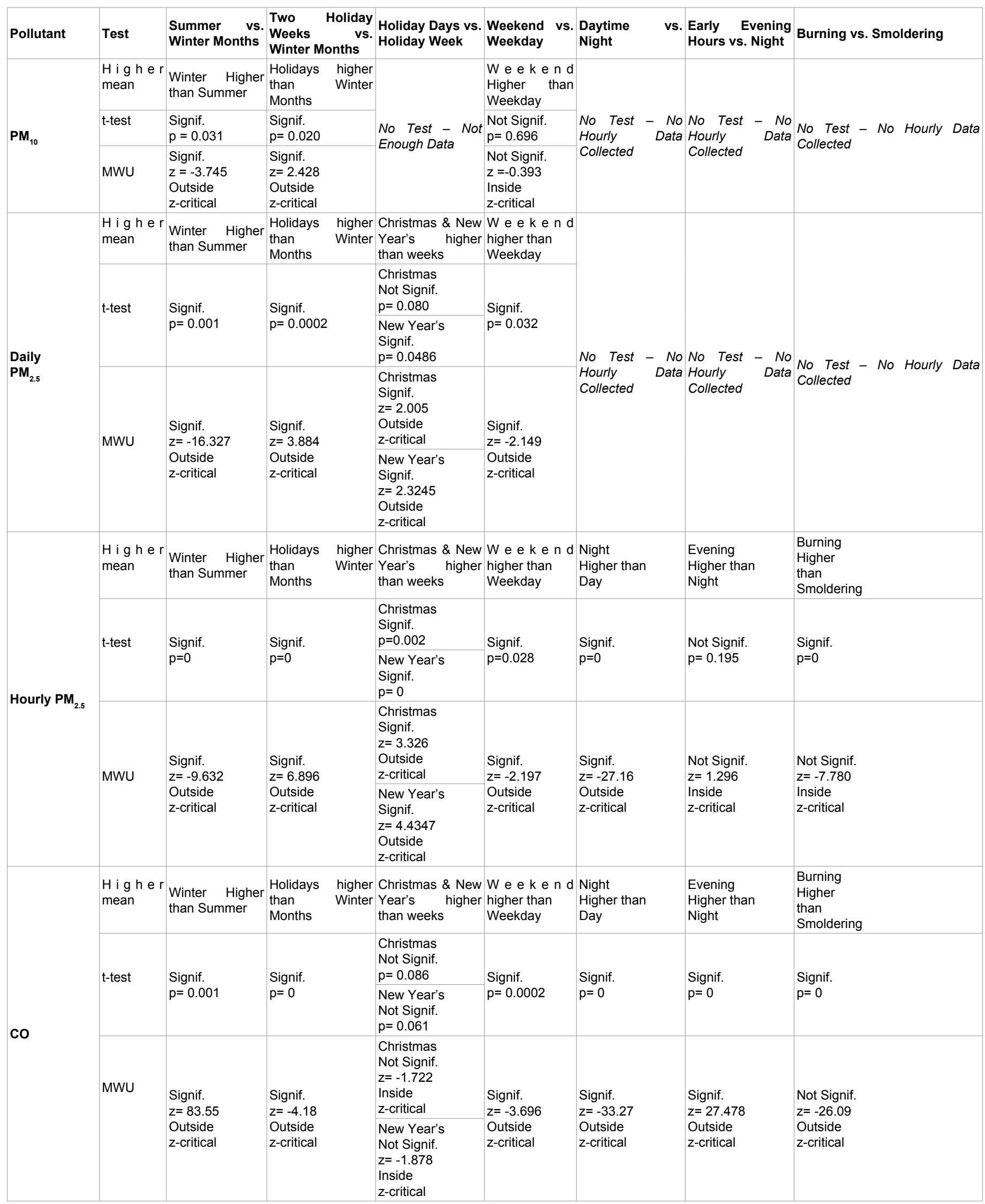

Table 2: Summary of Results from Both T-tests and MWU tests for $\mathrm{PM}_{10}$, Daily $\mathrm{PM}_{2.5}$, Hourly $\mathrm{PM}_{2.5}$, and CO. 


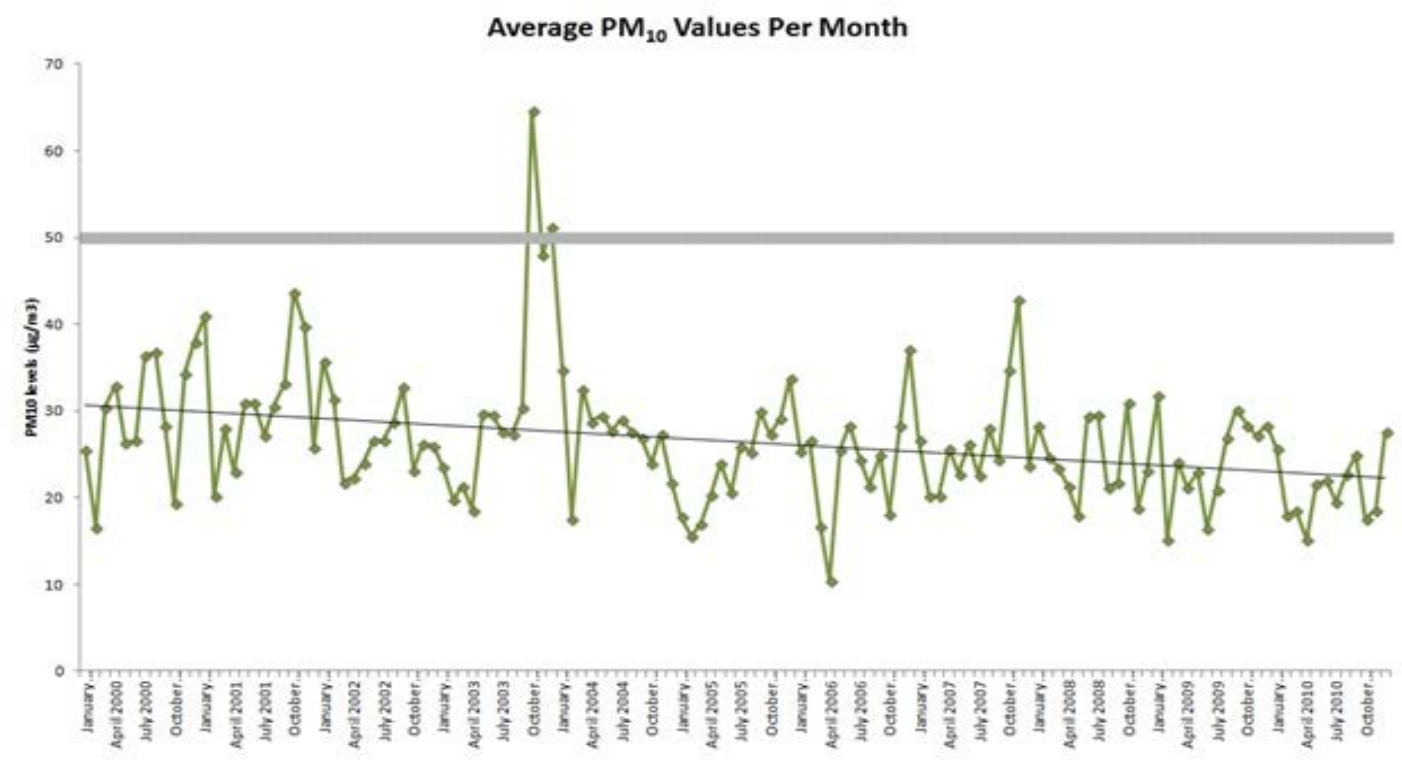

Figure 1: Display of $\mathrm{PM}_{10}$ data from January 1, 2000 to December 31, 2010 collected by SDAPCD in Escondido.

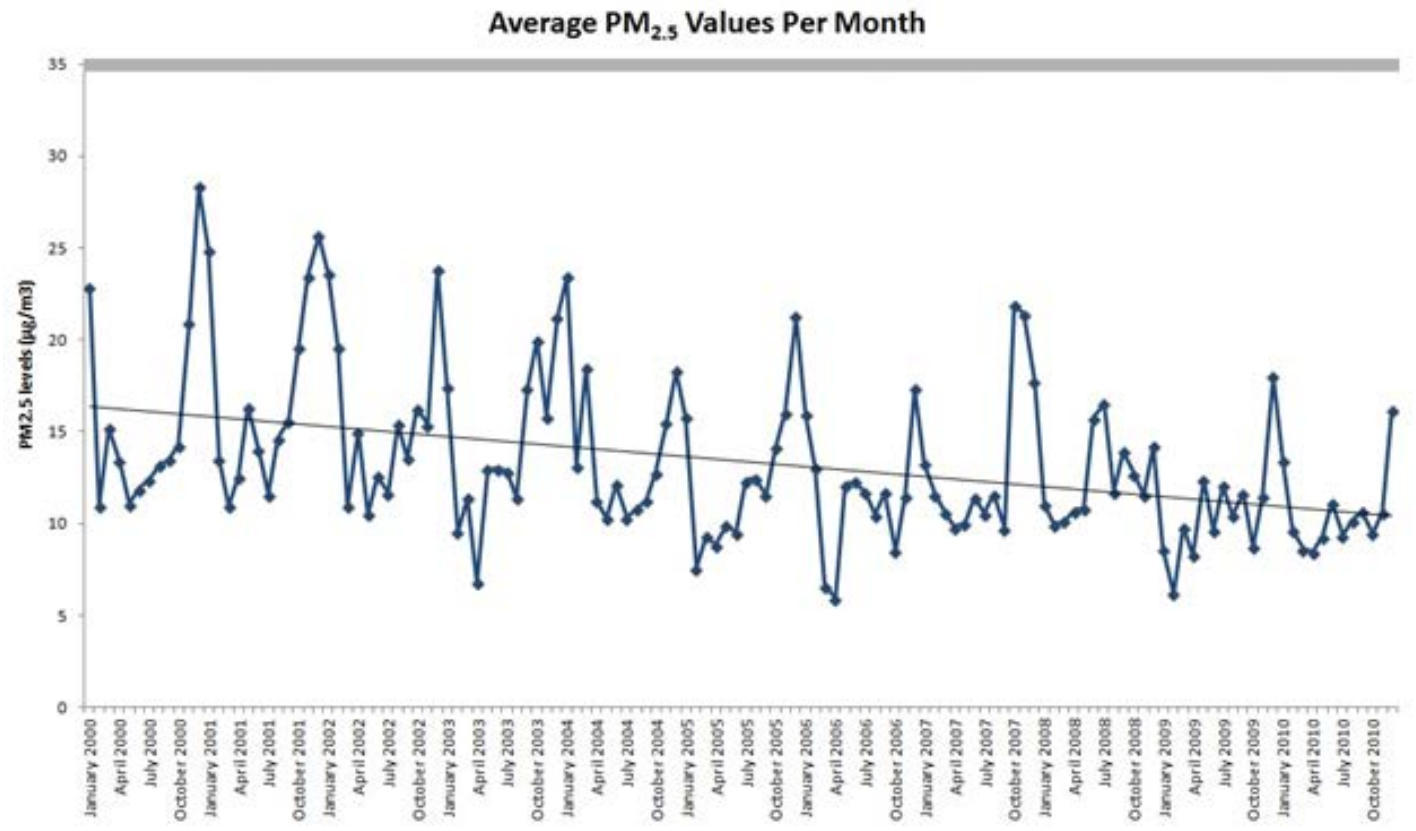

Figure 2: Display of $\mathrm{PM}_{25}$ monthly data collected by SDAPCD from January 1, 2000 to December 31, 2010 in Escondido. The bold line is the Federal 24-Hour Standard for $\mathrm{PM}_{2.5}$ at $35 \mu \mathrm{g} / \mathrm{m}^{3}$.

specific pollutant showed that there were higher ambient concentrations over the time period when fireplaces are used all night. Another source of these higher ambient concentrations to consider are fireworks used to celebrate the holiday. In order to determine if this was a likely source contributing to the higher ambient concentrations found on New Year's, the July $4^{\text {th }}$ period was plotted for each pollutant. For daily $\mathrm{PM}_{10}$ and $\mathrm{PM}_{2.5}$ values, the daily average concentrations were plotted from July $2^{\text {nd }}$ through July $6^{\text {th }}$. The hourly data for $\mathrm{PM}_{25}$ and $\mathrm{CO}$ were plotted as hourly concentration averages from midnight on July $4^{\text {th }}$ to $11: 00$ p.m. on July $5^{\text {th }}$ in order to observe any hourly changes across the July $4^{\text {th }}$ holiday.

\section{Traffic analysis}

Interstate 15 travels through Escondido and carries heavy commercial and other motorized vehicle traffic, whose emissions pollute Escondido's air throughout the year. To identify the impact of other possible major sources of $\mathrm{PM}_{10}, \mathrm{PM}_{2.5}$ and $\mathrm{CO}$ in the area, the traffic volume against ambient concentrations of each pollutant 
collected were plotted and analyzed over time. In this study, we were most interested in the time of year where PM and $\mathrm{CO}$ emissions impacted air quality, so we compared emissions data in January to traffic patterns. If the pattern of changes in emission levels matched, or mirrored in the case of a time delay, the volumes of traffic over the same time period, then it would be possible to attribute a portion of higher pollutant concentrations in the area to traffic.

Traffic data for 2012 for the Interstate 15 corridor, passing directly through Escondido and located three miles from the collection station were provided by SANDAG (San Diego Association of Governments). The study period's (2000-2010) traffic data were not available from SANDAG, but Caltrans PeMS system [21] provided data sets for traffic volume from 2000 to 2012 in Escondido. The data available from SANDAG were sorted and analyzed by time in the same way as the emissions data. An analysis of Total Vehicle Miles Traveled (representing traffic volume) against average ambient concentrations of each pollutant did not show any correlation or similar pattern. The graphs included daily traffic volumes versus $\mathrm{PM}_{10}$ and $\mathrm{PM}_{2.5}$ concentrations on weekdays (Figure 6) and on weekends (Figure 7), and hourly traffic volumes versus $\mathrm{PM}_{25}$ and $\mathrm{CO}$ concentrations during daytimes (Figure 8) and evenings (Figure 9).

Once it was found that the air quality difference between these two seasons was statistically significant, the emissions samples taken during the winter month weekdays were compared to the samples taken during the weekends (Table 2). This difference was attributed to the higher pollutant emissions emanating from fireplaces as opposed to traffic emissions. Wood burning stoves were also identified as a major emission source because in this area of Southern California, at least outside of the urban section of the city, stoves are used as an efficient way to heat the home. This study's results for weekends versus weekdays and days versus evenings also suggest that traffic is not the primary source of these particulate emissions.

\section{Speciated particulate matter analysis}

Speciated $\mathrm{PM}_{2.5}$ data were available year-round from 2001 to 2007, and were available as separate carbonaceous species that could be sorted and analyzed. Data were broken down into Total Elemental Carbon and Total Organic Carbon and compared to $\mathrm{PM}_{2.5}$ filter data that were collected on the same day. All three data sets were graphed, with the expectation that the sum of the elemental and organic carbon species would be the same as or less than the $\mathrm{PM}_{2.5}$ filter collection (Figure 10). The graph also shows that the carbon species increase and decrease at the same time as the carbon species collected on the filters. It was also shown that the portion of elemental carbon was always less than the portion of organic carbon. Table 3 shows the range and average of percentages of elemental and organic carbon species, separated by summer and winter to show the seasonal fluctuation that was also seen in filter tests.

\section{Conclusions}

During ideal biomass burning conditions, $\mathrm{CO}_{2}$ is produced $\left(\mathrm{CH}_{2} \mathrm{O}+\mathrm{O}_{2} \rightarrow \mathrm{CO}_{2}+\mathrm{OH}_{2}\right) \cdot \mathrm{CH}_{2} \mathrm{O}$ represents the composition of the average cellulose in wood [22]. In reality, methane, hydrocarbons, VOC's (Volatile Organic Compounds), and a large list of other

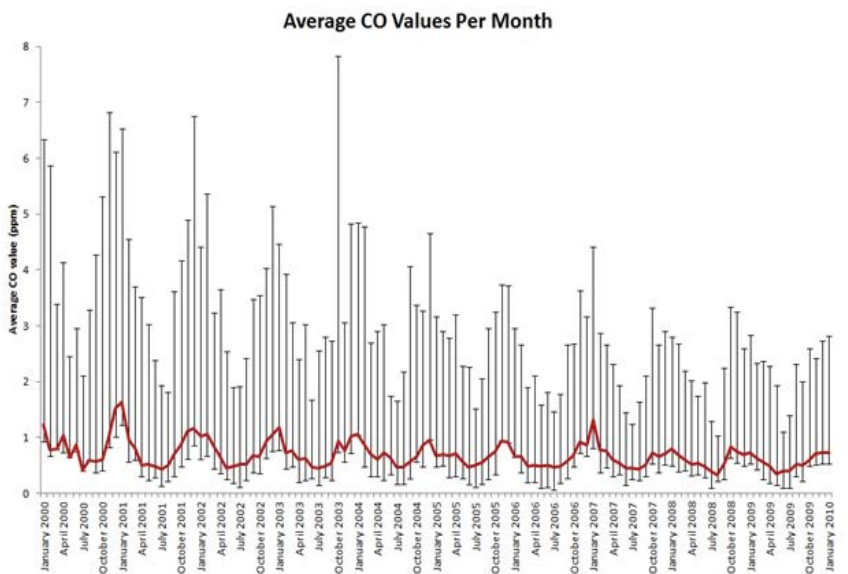

Figure 3: Average concentrations of $\mathrm{CO}(\mathrm{ppm})$ collected from January 2000 to January 2010. Graph includes minimum and maximum values for each monthly average shown. The CA state standard for hourly CO measured is $20 \mathrm{ppm}$. The federal standard is $35 \mathrm{ppm}$

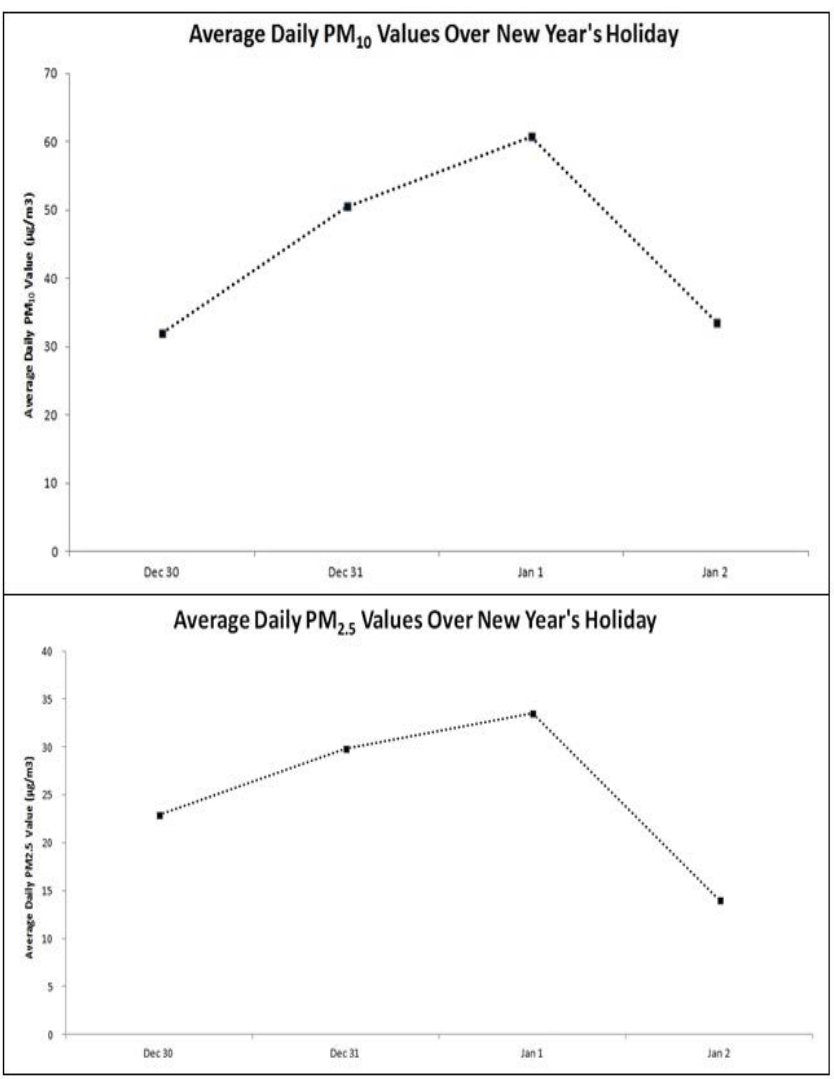

Figure 4: Plot of daily concentrations from December 30 to January 2 for years 2000 to 2010 highlighting the peak in values over the New Year's holiday. The upper graph illustrates $\mathrm{PM}_{10}$ average concentrations. The lower graph illustrates $\mathrm{PM}_{2.5}$ average concentrations.

\begin{tabular}{|c|c|c|c|c|}
\hline Period & Range of Elemental Carbon \% & Average Elemental Carbon \% & Range of Organic Carbon \% & Average Organic Carbon \% \\
\hline Summer & $0 \%-20 \%$ & $5 \%$ & $12 \%-100 \%$ & $38 \%$ \\
\hline Winter & $0 \%-27 \%$ & $7 \%$ & $5 \%-89 \%$ & $50 \%$ \\
\hline
\end{tabular}

Table 3: Range and average percentages of elemental and organic carbon species in the summer and winter. 
Citation: Sarah E, Jorge C, Shekar V, William CB (2015) Effects of Residential Wood-Burning Emissions during Winter Months in a Northern San Diego County Location. J Environ Anal Toxicol 5: 266. doi:10.4172/2161-0525.1000266

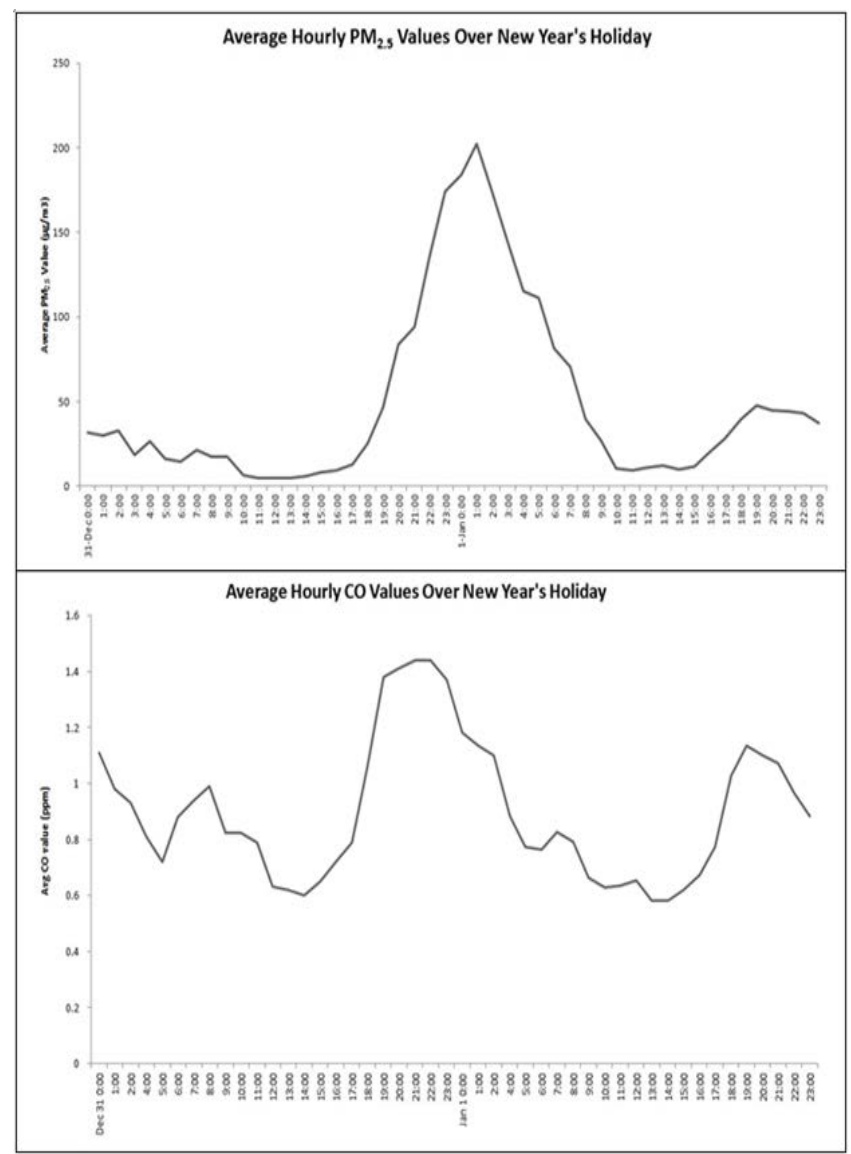

Figure 5: Plot of hourly concentrations of CO for years 2000 to 2010 and 2008 to 2010 for $\mathrm{PM}_{25}$, from December 31 to January 1, highlighting the peak in values over the New Year's holiday. The upper graph illustrates hourly $\mathrm{PM}_{25}$ average concentrations. The lower graph illustrates hourly $\mathrm{CO}$ average concentrations.

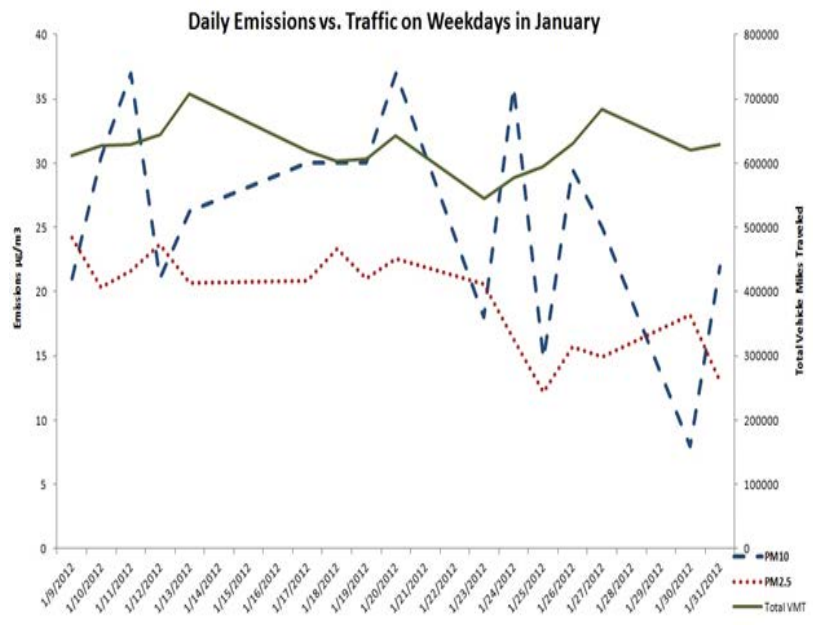

Figure 6: Traffic volume (Vehicle Miles Traveled) collected daily graphed with $\mathrm{PM}_{10}$ and $\mathrm{PM}_{25}$ daily data $\left(\mu \mathrm{g} / \mathrm{m}^{3}\right)$ on weekdays. Traffic data was available in January for 2012. Particulate data was available each January from 2000 to 2010 and averaged.

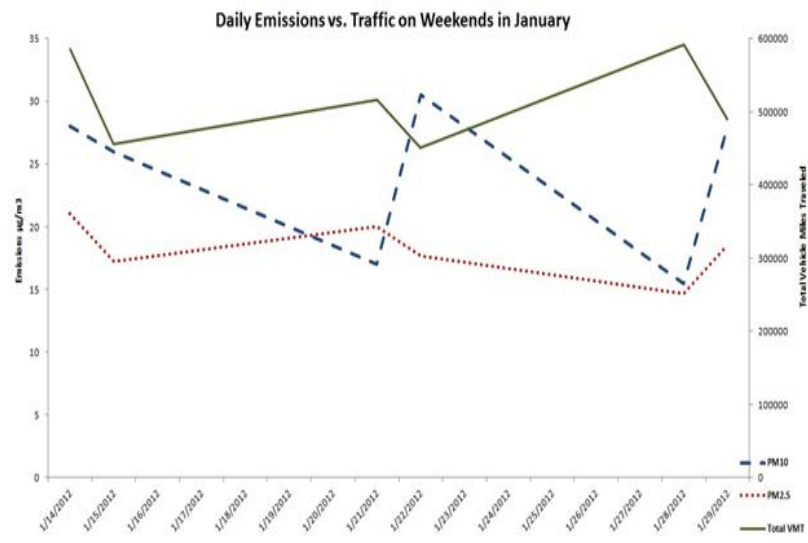

Figure 7: Traffic volume (Vehicle Miles Traveled) collected daily graphed with $\mathrm{PM}_{10}$ and $\mathrm{PM}_{2.5}$ daily data $\left(\mu \mathrm{g} / \mathrm{m}^{3}\right)$ on weekends. Traffic data was available in January for 2012. Particulate data was available each January from 2000 to 2010 and averaged.

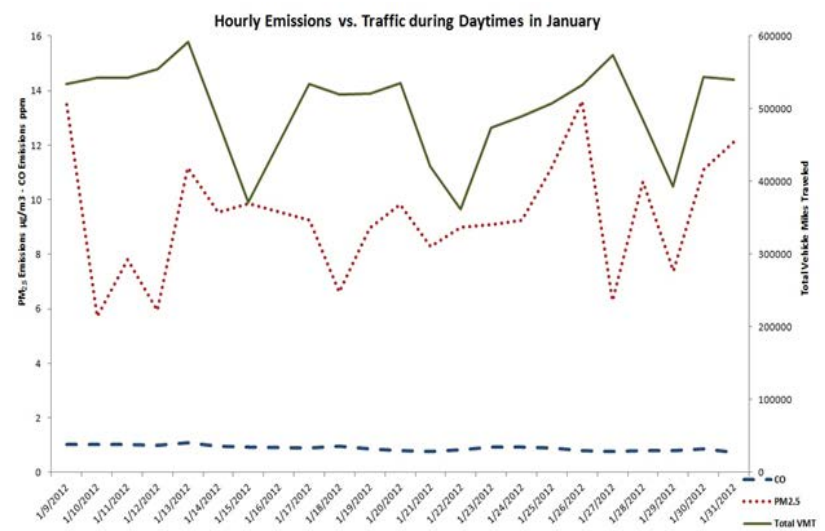

Figure 8: Traffic volume (Vehicle Miles Traveled) collected hourly graphed with $\mathrm{PM}_{25}$ hourly $(\mu \mathrm{g} / \mathrm{m} 3)$ and CO hourly $(\mathrm{ppm})$ data during the daytime (7am to $6 \mathrm{pm}$ ). Traffic data was available in January for 2012. Particulate data was available each January from 2008 to 2010 . CO data was available each January from 2000 to 2010 . Each were averaged over all years available.

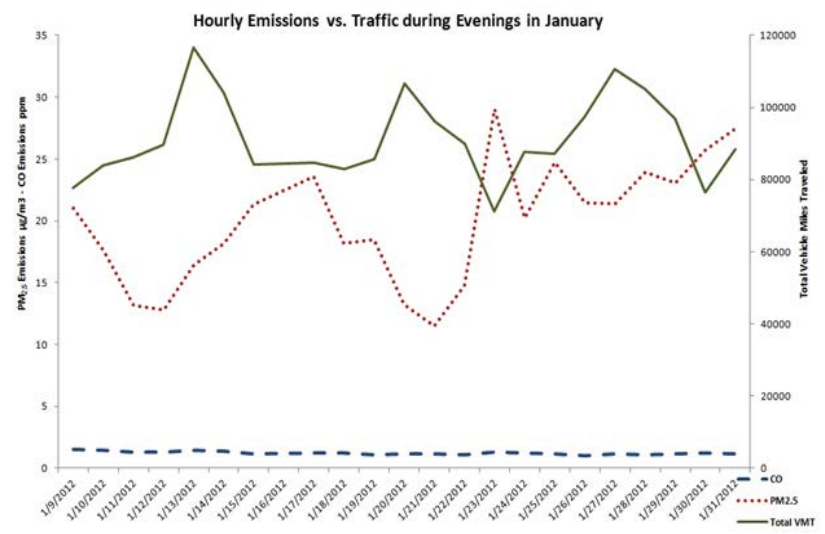

Figure 9: Traffic volume (Vehicle Miles Traveled) collected hourly graphed with PM hourly $\left(\mu \mathrm{g} / \mathrm{m}^{3}\right.$ ) and CO hourly (ppm) data in the evenings (7pm to $12 a m$ ). Traffic data was available in January for 2012. Particulate data was available each January from 2008 to 2010 . CO data was available each January from 2000 to 2010 . Each were averaged over all years available. 


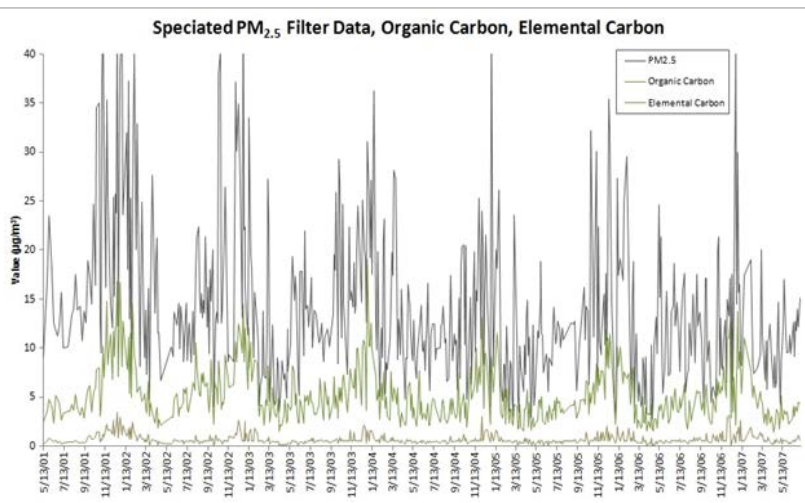

Figure 10: Plot of $\mathrm{PM}_{25}$ filter data with organic carbon and elemental carbon data for the same dates. All data sets are in $\mu \mathrm{g} / \mathrm{m}^{3}$.

contaminants can be released into the air during wood burning [23].

Comparison of the results between burning and smoldering tests indicate that the products of wood burning combustion change with the fireplace temperature. As the fire changes from burning to smoldering, ambient concentrations of $\mathrm{CO}$ increase. All types of combustion reactions have efficiency values that vary in accordance with the combustion chamber temperature. The temperature inside the fireplace decreases throughout the time it is used, and the amount of particulate emissions generated increases as fire temperature decreases, making smoldering and initial burning the most impactful combustion occurrences [2].

$\mathrm{PM}_{10}, \mathrm{PM}_{2.5}$, and $\mathrm{CO}$ data sets collected at the SDAPCD Escondido monitoring station from 2000 to 2010 showed higher ambient concentrations of pollutants in the winter and around the winter holidays. These higher concentrations were attributed to larger emissions during times of fireplace usage. This conclusion was drawn by eliminating traffic as a major source of these emissions, and by separating carbonaceous species that showed a relationship with the particulate filter data sets. As expected, the concentration of pollutants present in the air was significantly different between winter and summer. The results suggest that differences in measured concentrations may have been due in part to fireplace wood burning, along with more stable atmospheric conditions during winter months.

The hourly CO data collected were more extensive than the daily particulate data collected. This allowed for flexibility in the analysis and they also made it easy to isolate measurements based on times of the day. Data could be sorted into various groups since each data point collected was paired with a time of day. Results of the weekday versus weekend tests, as well as the daytime versus nighttime, and early evening versus nighttime tests, show that higher concentrations of $\mathrm{CO}$ (Table 2) at these times likely comes from the use of fireplaces as opposed to other area sources because concentrations are significantly higher at specific times when people are home and using their fireplaces, furnaces, and water heaters.

\section{Acknowledgement}

The authors would like to acknowledge the critical review done by the reviewers and their constructive comments.

\section{References}

1. Pierson WE, Koenig JQ, Bardana EJ (1989) Potential Adverse Health Effects of Wood Smoke. The Western Journal of Medicine 151: 339-341.

2. Gaeggeler K, Prevot ASH, Dommen J, Legreid G, Reimann S, et al. (2008) Residential Wood Burning in an Alpine Valley as a Source for Oxygenated
Volatile Organic Compounds, Hydrocarbons, and Organic Acids. Atmospheric Environment 42: 8278-8287.

3. Maenhaut W, Vermeylen R, Claeys M, Vercauteren J, Matheeuseen C, et al. (2012) Assessment of the Contribution from Wood Burning to the PM aerosol in Flanders, Belgium. Science of the Total Environment 437: 226-236.

4. Bari Md, Baumbach G, Kuch B, Scheffknecht G (2009) Wood Smoke as a Source of Particle-Phase Organic Compounds in Residential Areas. Atmospheric Environment 43: 4722-4732.

5. Borrego C, Valente J, Carvalho A, Sá EM Lopes, Miranda Al (2010) Contribution of Residential Wood Combustion to $\mathrm{PM}_{10}$ Levels in Portugal. Atmospheric Environment 44: 642-651.

6. Kleeman MJ, Robert M, Riddle SG, Fine PM, Hays MD, et al. (2008) Size Distribution of Trace Organic Species Emitted from Biomass Combustion and Meat Charbroiling. Atmospheric Environment 42: 3059-3075.

7. Morandi MT, Ward TJ (2010) Wood smoke risk assessment: defining the questions. Risk Assessment Workgroup 22: 94-98.

8. Tian QY, Radke JD, Gong P, Yu Q (2004) Model development for spatial variation of $\mathrm{PM}_{25}$ emissions from residential wood burning. Atmospheric Environment 38: 833-843.

9. http://www.escondido.org/demographics.aspx

10. http://www.ncdc.noaa.gov/cdo-web/search

11. http://www.epa.gov/apti/course422/ap3.html

12. Staff M, Heidi E, Aunan K, Seip HM (2007) Health benefits from reducing indoor air pollution from household solid fuel use in China - Three abatement scenarios. Environment International 33: 831-840.

13. Sexton K, John DS, Robert DT, William AT (1984) Winter air quality in a wood-burning community: A case study in Waterbury, Vermont. Atmospheric Environment 18: 1357-1370.

14. Kinsey J, Kariher P, Dong $Y$ (2009) Evaluation of methods for the physical characterization of the fine particle emissions from two residential wood combustion appliances. Atmospheric Environment 43: 4959-4967.

15. Harry F (1989) Standard Handbook of Hazardous Waste Treatment and Disposal In: Pyrolysis Processes, Shah J McGraw-Hill Company, New York.

16. Lewtas J (2007) Air pollution combustion emissions: Characterization of causative agents and mechanisms associated with cancer, reproductive, and cardiovascular effects. Mutation Research/Reviews in Mutation Research 636: 95-133.

17. Viswanathan S, Eria L, Diunugala N, Johnson J, McClean C (2005) An Analysis of Effects of San Diego Wildfire on Ambient Air Quality. Air and Waste Management Journal 56: 56-67.

18. Agrawal H, Sawant A, Jansen K, Miller JW, Cocker D (2008) Characterization of Chemical and Particulate Emissions from Aircraft Engines. Atmospheric Environment 42: 4380-4392.

19. http://www.ncdc.noaa.gov/stormevents/

20. www.sdapcd.org/info/reports/2009_annual_rpt.pdf

21. http://pems.dot.ca.gov/

22. Neves D, Thunman H, Matos A, Tarelho L, Gomez-Barea A (2011) Characterization and Prediction of Biomass Pyrolysis Products. Progress in Energy and Combustion Science 37: 611-630.

23. Heikki L, Kati N, Jarkko T, Jarno R, Pasi Y, et al. Physicochemical characterization of fine particles from small-scale wood combustion. Atmospheric Environment 45: 7635-7643. 